\title{
A Study on Antifungal Properties of Azadirachta indica, Coriandrum sativum Linn. and Mentha piperita Linn. Plant Extract on Sclerotium rolfsii Causing Root Rot of Chilli
}

\author{
Uzma Quadri $^{1}$, Sumia Fatima ${ }^{2}$ \\ ${ }^{1}$ Research Student, Department of Botany, Pesticide and Plant Protection Research Laboratory, Dr. Rafiq Zakaria College for Women \\ Campus-2, Navkhanda, Jubliee park, District-Aurangabad- 431001, Maharashtra (MS), India. \\ ${ }^{2}$ Associate Professor, Department of Botany, Pesticide and Plant Protection Research Laboratory, Dr. Rafiq Zakaria College for Women \\ Campus-2, Navkhanda, Jubliee park, District-Aurangabad- 431001, Maharashtra (MS), India.
}

\begin{abstract}
Medicinal plant are great source of thousands new useful phytochemicals of great diversity, which have inhibitory effects on all types of microorganisms in vitro. The present study focus on the leaves extract of Azadirachta indica (neem), Coriandrum sativum Linn. and Mentha piperita Linn at concentration was ranging from 10\%, 25\%, 50\%, 75\%, $100 \%$ (without treatment served as control) in aqueous medium. In the potato dextrose agar medium the inhibited the Sclerotium rolfsii causing root rot diseases in chilli was assessed by poisoned food technique. All three extract inhibited radial growth at various levels. Among three leaves extract tested, Coriandrum sativum Linn showed strong $(70.25 \%$ of inhibition) at with both $16.66 \mathrm{~mm}$ inhibited at 10 \& 50 percent concentration of aqueous leaves extract after 48 hours incubation period. The Mentha piperita Linn recorded moderate percentage of inhibition ranges from 7.372 to 63.56 with $79.66 \mathrm{~mm} \& 31.33 \mathrm{~mm}$ inhibited radial mycelial at 10 and 50 percent aqueous medium leaves extract concentration after 72 hours of incubation period. The least percent of inhibition was recorded in Azadirchta indica as 35.92 with 16.66mm inhibited mycelial it was followed by 35.46 percent of inhibition with $40.66 \mathrm{~mm}$ mycelial growth at 25 \& 50 percent concentration after 24 \& 48 hours of incubation period respectively. Also fungicidal activity recorded by Azadirachta indica that is $0 \%$ to $4.267 \%$ of inhibition with 63 mm to $82.33 \mathrm{~mm}$ at 50, 75 (for 0\%) and 10 concentrations of leaves extracts after 48 hours and 72 hours of incubation period. These above three medicinal plants are abundant, easily available and have potential fungicidal activity.
\end{abstract}

Keywords: Antifungal activity, Azadirachta indica, Coriandrum sativum Linn and Medicinal plants, Mentha peperita and Sclerotium rofsii.

\section{Introduction}

In agriculture, the crop loss due to plant fungal pathogens has become measured concern. There are numerous diseases arise whenever the vegetables are grown attack by fungal pathogen, like root rot of chilli the causal agent of Sclerotium rolfsii is the most common and distractive diseases, responsible for significant economic losses, these leading to reduction in economic yield. There are very few methods applicable for controlling the root rot diseases. The fungi Sclerotium rolfsii are soil inhabiting pathogens with wide host range and there by very difficult to control them [1].

Medicinal plants were used as excellent antifungal agents because it poses a verity of chemical constituents is nature recently much attention has directed towards extracts and biologically active compound isolated from popular plant species. The use of plants and plant material as fungicide are great importance, which need more attention [2]. The bioticcontrol of plant diseases may have minimum adverse effect on physiological presses of plant and less environmental hazards [3] as well may create a fewer health problems compared to synthetics alternatives. Biological active compound found in plant appeared to be more adaptable, acceptable and safer than synthetic compounds and display a wealthy source of potential pathogen control agent [4]. Their large demand for new fungicide for use in food protection, agriculture and medicine. Crude extracts of some well know medicinal plants are used to control some of the plant pathogens [5]. The use of synthetic chemicals as antimicrobial for the management of plant diseases has double increased crop production but with considerable detritions of environment quality and plant health [6].

The purpose of this trail was to evaluate the efficacy of for the in-vitro inhibition of Sclerotium rolfsii. Medicinal plant extracts such as Azadirachta indica (var.name neem) inhibitors are often used in the control of plant diseases in agriculture and add with notes of who reported that active compound of neem are distributed throughout the tree plants but are concentrated in seeds and are concentrated in leaves was extractable by water. The present investigation aims to find out and evaluate the antifungal activity of the crude extracts from Azadirachta indica (neem), Coriandrum sativum Linn. and Mentha piperita Linn medicinal plants leaves on the Sclerotium rolfsii fungus growth.

\section{Materials and Methods}

Isolation of Sclerotium rolfsii.

Infected root rot disease of chilli plant caused by Sclerotium rolfsii was collected from the field of Aurangabad District. The cut the infected portion into small pieces of about 3$5 \mathrm{~mm}$ thick and sterilized with $0.1 \%\left(\mathrm{HgCl}_{2}\right)$ mercuric chloride solution for few seconds and rinsed thrice in sterilized distilled water, and then placed on filter paper at 


\section{International Journal of Science and Research (IJSR) \\ ISSN (Online): 2319-7064 \\ Index Copernicus Value (2013): 6.14 | Impact Factor (2015): 6.391}

room temperature. The tissue sections were then placed on potato dextrose agar and incubated at room temperature for seven days. Ultimately the pure culture of the pathogen was isolated subsequently maintained on the potato dextrose agar medium. Potato dextrose agar medium was prepared and after lower the temperature poured in petriplates of the medium, mycelial disk $4 \mathrm{~mm}$ diameter were cut from 4-5 day-old actively growing culture of Slcerotium rolfsii and each was placed in the center of petriplates containing potato dextrose agar medium. The effect of plant extracts on inhibition of the Sclerotium rolfsii was studied using poisoning food technique [7].

\section{Plant species with families selected}

The effect of plant extracts on mycelial growth of Sclerotium rolfsii in-vitro evaluated. Plant species and families used for this study were presented in the Table 1 below.

Table 1: The plant species and families

\begin{tabular}{|c|c|c|}
\hline Sr. No. & Botanical name of medicinal Plants & Families \\
\hline 1 & Azadirachta indica & Meliaceae \\
\hline 2 & Coriandrum sativum Linn & Umbelliferae \\
\hline 3 & Mentha piperita Linn & Myrtaceae \\
\hline
\end{tabular}

\section{Preparations' of plant extract}

Fresh leaves of Azadirachta indica (neem), Coriandrum sativum Linn and Mentha piperita Linn were used medicinal plants leaves extract preparations. These leaves were collected from Dr. Rafiq Zakaria College for Women Campus -2 and local vegetable market during January, February 2015. These plants leaves, were rinsed in sterile distilled water in two to three times and dried in shied at room temperature, after which they were milled motor and pestle and electric blender to make powder. The powders were packed in to bottles and in air tight plastic pouches.

\section{Preparation plant leaves extract medium for different concentration:}

The plant leaves extract were made with at the rate of one $\mathrm{ml} /$ one gm or one $\mathrm{gm} /$ one $\mathrm{ml}$ of sterilized distilled water, autoclaved, cooled and then strained through muslin cloth. This formed a standard plant extract were made in aqueous medium of $10 \%, 25 \%, 50 \%, 75 \%$ and control (a without plant leaves extracts) concentrations.

\section{Studies effect of plant leaves extracts of different concentrations:}

The effect of plant leaves extracts of Azadirachta indica (neem), Coriandrum sativum Linn and Mentha piperita Linn on inhibit the Sclerotium rolfsii was studied using poisoning food technique [7]. From standard stock solutions of plants leaves $10,25,50,75$ percentage concentrations was prepared separately by adding the required quantity of plants extract to the molten potato dextrose agar medium. One set is made without plant extract and keep it as controlled. All theses poured in to sterilized Petri plates. A mycelial disk cut from the periphery to 3-4 days old colony of Sclerotium rolfsii grown on potato dextrose agar medium were centrally placed in each of the Petri plates containing the potato dextrose agar medium having different three medicinal plant leaves of Azadirachta indica (neem), Coriandrum sativum Linn and Mentha piperita Linn at different 10\%, 25\%, 50\%, 75\% concentrations and control kept under aseptic conditions. The Petri plates contains the PDA medium inoculated with the pathogen alone served as control. All these Petri plates were incubated at room temperature. There are three replication were maintained for each treatment. The diameter of the colony was measured in two directions and average was recorded. The inhibition the Sclerotium rolfsii was calculated by using the formula given below.

Percentage of inhibition

$=$ [Diameter of colony] $-[$ Diameter of colony in treatment $]$ Diameter of colony control

$$
\times 100
$$

Table 1: Medicinal plants in aqueous medium of following concentrations impression radial growth of Sclerotium rolfsii measured in $\mathrm{mm}$ after 24 hours.

\begin{tabular}{|c|c|c|c|c|c|}
\hline $\begin{array}{c}\text { Serial. } \\
\text { No }\end{array}$ & $\begin{array}{l}\text { Medicinal } \\
\text { plants }\end{array}$ & $\begin{array}{c}\text { Concentrations } \\
(\%)\end{array}$ & Growth & S.rolfsii & Given \\
\hline & & & extracts & measured & in $\mathrm{mm}$ \\
\hline & & & & 24 hours & \\
\hline & & & $24 \mathrm{hr}$ & $48 \mathrm{hr}$ & $72 \mathrm{hr}$ \\
\hline \multirow{5}{*}{10} & \multirow{5}{*}{$\begin{array}{l}\text { Coriandrum } \\
\text { sativum Linn. }\end{array}$} & $10 \%$ & 20.66 & 16.66 & 76.33 \\
\hline & & $25 \%$ & 18.66 & 49.33 & 70.33 \\
\hline & & $50 \%$ & 20.33 & 16.66 & 63.66 \\
\hline & & $75 \%$ & 20.33 & 39.66 & 62 \\
\hline & & Control & & & \\
\hline \multirow{5}{*}{11} & \multirow{5}{*}{$\begin{array}{c}\text { Mentha } \\
\text { piperita Linn. }\end{array}$} & $10 \%$ & 23.33 & 48.66 & 79.66 \\
\hline & & $25 \%$ & 20.33 & 46 & 70.66 \\
\hline & & $50 \%$ & 15 & 23.33 & 31.33 \\
\hline & & $75 \%$ & 19.66 & 39 & 52.33 \\
\hline & & Control & & & \\
\hline \multirow{5}{*}{12} & \multirow{5}{*}{$\begin{array}{l}\text { Azadirachta } \\
\text { indica (neem) }\end{array}$} & $10 \%$ & 22.33 & 54 & 82.33 \\
\hline & & $25 \%$ & 16.66 & 40.66 & 60 \\
\hline & & $50 \%$ & 16.66 & 64 & 64 \\
\hline & & $75 \%$ & 18.66 & 63 & 63 \\
\hline & & Control & & & \\
\hline
\end{tabular}

* Values are average of triplicate.

* Values measured after deducting or reducing $4 \mathrm{~mm}$ mycelium disk.

* (I) is denoted for inhibition.

* Note $1-10 \%, 25 \%, 50 \%, 75 \%$ and Control (100\%) are aqueous medium leaves extract. 


\section{International Journal of Science and Research (IJSR) ISSN (Online): 2319-7064}

Index Copernicus Value (2013): 6.14 | Impact Factor (2015): 6.391

Table 2: The percentage of Inhibition (\% of I) of Sclerotium rolfsii at given plant extract concentration in aqueous medium

\begin{tabular}{|c|c|c|c|c|c|c|c|c|}
\hline \multirow{2}{*}{$\begin{array}{c}\text { Serial. } \\
\text { No }\end{array}$} & \multirow{2}{*}{$\begin{array}{l}\text { Medicinal } \\
\text { plants }\end{array}$} & Concentrations (\%) & $\begin{array}{l}\text { Percentage } \\
\text { Given }\end{array}$ & $\begin{array}{c}\text { of } \\
\text { plant }\end{array}$ & $\begin{array}{c}\text { Inhibition (I) } \\
\text { extract }\end{array}$ & $\begin{array}{l}\text { Of } \\
\text { In }\end{array}$ & $\begin{array}{c}\text { S.rolfsii } \\
\text { following }\end{array}$ & $\begin{array}{c}\text { At } \\
\text { concentration }\end{array}$ \\
\hline & & & $24 \mathrm{hr}$ & $\%$ of I & $48 \mathrm{hr}$ & $\%$ of I & $72 \mathrm{hr}$ & $\%$ of I \\
\hline \multirow{5}{*}{10} & \multirow{5}{*}{$\begin{array}{l}\text { Coriandrum } \\
\text { sativum Linn }\end{array}$} & $10 \%$ & 20.66 & 20.53 & 16.66 & 70.25 & 76.33 & 11.24 \\
\hline & & $25 \%$ & 18.66 & 28.23 & 49.33 & 11.91 & 70.33 & 18.22 \\
\hline & & $50 \%$ & 20.33 & 21.80 & 16.66 & 70.25 & 63.66 & 25.97 \\
\hline & & $75 \%$ & 20.33 & 21.80 & 39.66 & 29.17 & 62 & 27.90 \\
\hline & & Control & & & & & & \\
\hline \multirow{5}{*}{11} & \multirow{5}{*}{$\begin{array}{c}\text { Mentha } \\
\text { piperita } \\
\text { Linn. }\end{array}$} & $10 \%$ & 23.33 & 10.26 & 48.66 & 17.10 & 79.66 & 7.372 \\
\hline & & $25 \%$ & 20.33 & 21.80 & 46 & 17.85 & 70.66 & 17.83 \\
\hline & & $50 \%$ & 15 & 42.30 & 23.33 & 58.33 & 31.33 & 63.56 \\
\hline & & $75 \%$ & 19.66 & 24.38 & 39 & 30.35 & 52.33 & 39.15 \\
\hline & & Control & & & & & & \\
\hline \multirow{5}{*}{12} & \multirow{5}{*}{$\begin{array}{c}\text { Azadirachta } \\
\text { indica } \\
\text { (neem) }\end{array}$} & $10 \%$ & 22.33 & 14.11 & 54 & 14.28 & 82.33 & 4.267 \\
\hline & & $25 \%$ & 16.66 & 35.92 & 40.66 & 35.46 & 60 & 30.23 \\
\hline & & $50 \%$ & 16.66 & 35.92 & 64 & 0 & 64 & 25.58 \\
\hline & & $75 \%$ & 18.66 & 28.23 & 63 & 0 & 63 & 26.74 \\
\hline & & Control & & & & & & \\
\hline
\end{tabular}

* Values are average of triplicate.

* Values measured after deducting or reducing $4 \mathrm{~mm}$ mycelium disk.

* (I) is denoted for inhibition.

* Note $2-10 \%, 25 \%, 50 \%, 75 \%$ and Control (100\%) are aqueous medium leaves extract.

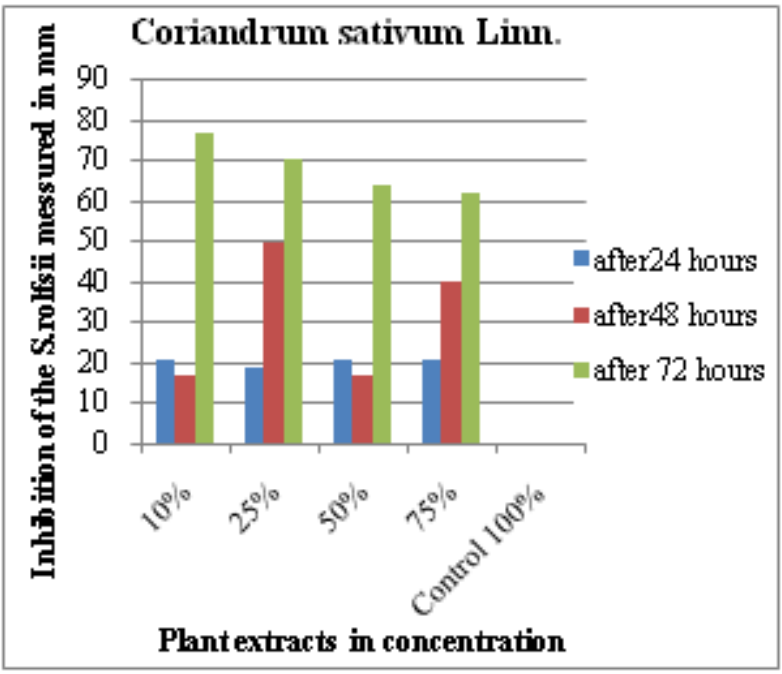

Graph 1- Inhibition of the Sclerotium rolfsii in Coriandrum sativum Linn leaves extract.
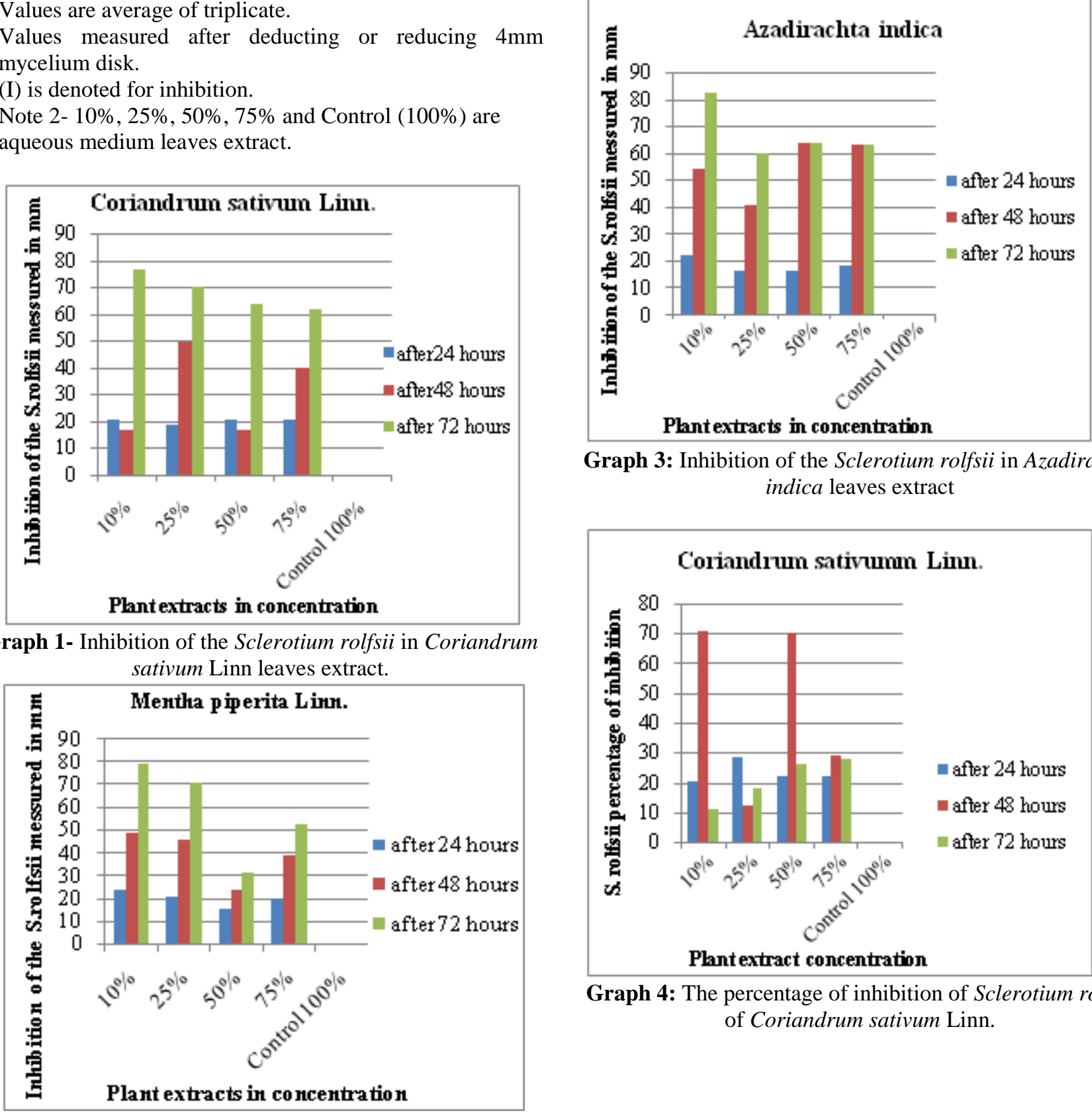

Graph 3: Inhibition of the Sclerotium rolfsii in Azadirachta indica leaves extract

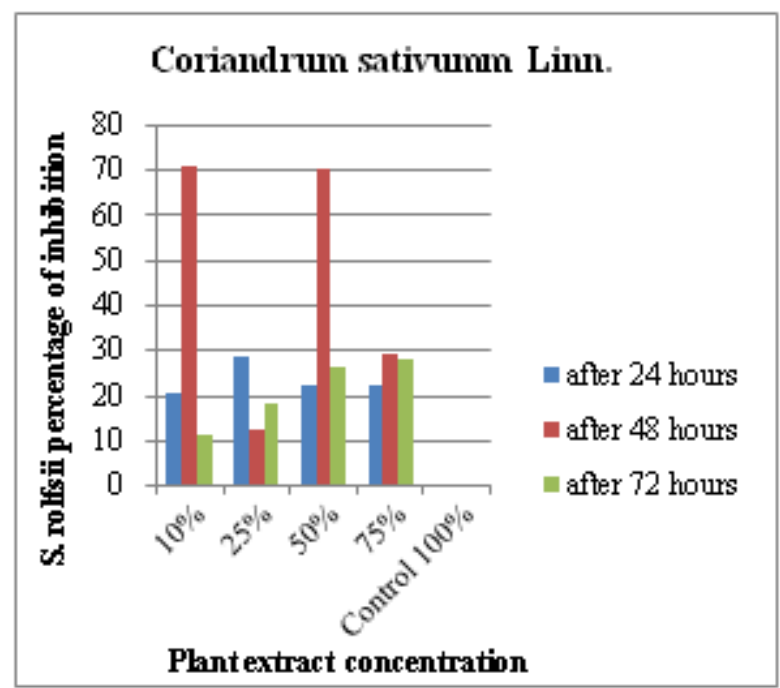

Graph 4: The percentage of inhibition of Sclerotium rolfsii of Coriandrum sativum Linn.

Graph 2- Inhibition of the Sclerotium rolfsii in Mentha piperita Linn(Mint) leaves extract.

Volume 5 Issue 6, June 2016 www.ijsr.net

Licensed Under Creative Commons Attribution CC BY 


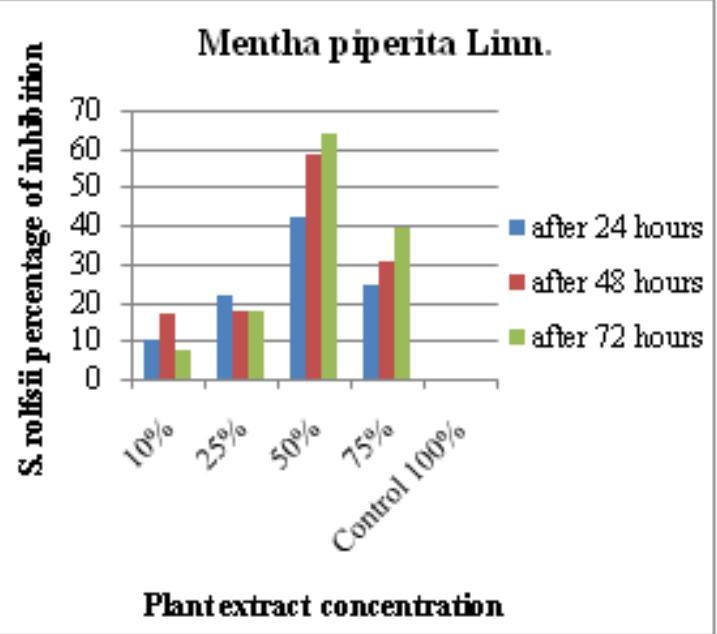

Graph 5: The percentage of inhibition of Sclerotium rolfsii of Mentha piperita (mint).

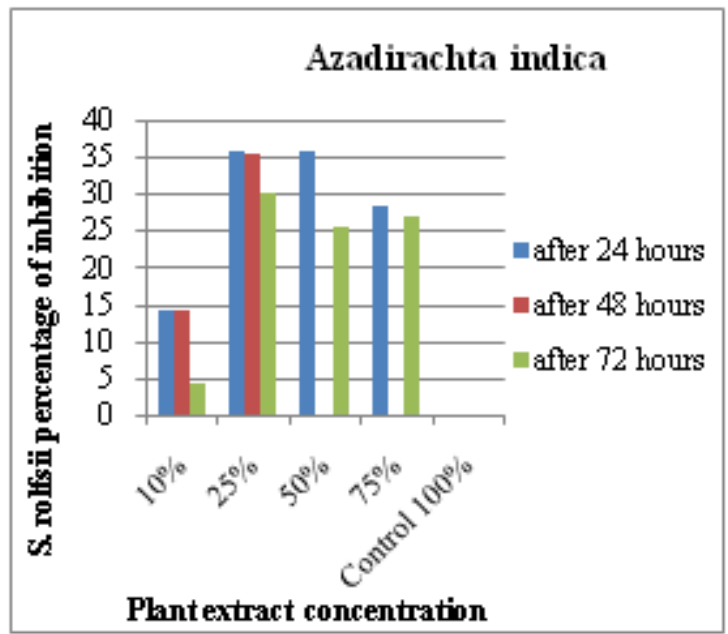

Graph 6- The percentage of inhibition of Sclerotium rolfsii of Azadirachta indica Linn (neem).

\section{Result and Discussion}

The antifungal activity of medicinal plant extract of Azadirachta indica (neem), Coriandrum satavium Linn and Mentha piperita Linn were studied in different concentration against pathogenic fungus Sclerotium rolfsii table 1, 2, 3 and graph 1-6, it revealed that Coriandrum sativum Linn. gave strongest percent of inhibition 70.25 with $16.66 \mathrm{~mm}$ inhibited mycelial at 10 and 50 percent concentration after 48 hours of incubation period. This was followed by 28.23 percent of inhibition with $18.66 \mathrm{~mm}$ inhibited mycelial at 25 percent concentration after 24 hours of incubation period. The least percent of inhibition in Coriandrum sativum was 11.24 followed by 18.22 with $76.33 \mathrm{~mm} \& 70.33 \mathrm{~mm}$ inhibited mycelial. The Mentha piperita Linn. recorded moderate percentage of inhibition that is 63.56 with $31.33 \mathrm{~mm}$ inhibited mycelial followed by 58.33 percent of inhibition with $23.33 \mathrm{~mm}$ inhibited mycelial at 50 percent concentration plant extract after 72 hours and 48 hours of incubation periods. The least percent of inhibition in Mentha piperita was 7.372 followed by 10.26 with $79.66 \mathrm{~mm} \& 23.33 \mathrm{~mm}$ inhibited mycelial after 72 hours and 24 hours respectively. The least percent of inhibition was recorded in Azadirchta indica as 35.92 with $16.66 \mathrm{~mm}$ inhibited mycelial it was followed by 35.46 percent of inhibition with $40.66 \mathrm{~mm}$ mycelial growth at $25 \& 50$ percent concentration after $24 \&$ 48 hours of incubation period respectively. The zero percent of inhibition was also found in Azadirachta indica at 50 \& 75 percent concentration after 48 hours of incubation period.

\section{Discussion}

In this study of all three leaf extracts effectively suppressed mycelial growth were never found at all concentrations completely suppressed the Sclerotium rolfsii. It also wellknown the inhibitory effect of leaf extract Azadirachta indica on growth of different fungi were found to have inhibitory, but the inhibitory effect of leaves extract of Coriandrum satavium Linn and Mentha piperita Linn was evolved first time against Sclerotium rolfsii.

In conclusion, the present study explores the possibilities of controlling Sclerotium rolfsii by using medicinal plants Azadirachta indica (neem), Coriandrum satavium Linn and Mentha piperita Linn leaves extracts and highlights on encouraging the possible application.

\section{Conclusion}

The fungicidal efficacy of three medicinal plants leaves extracts was tested against Sclerotium rolfsii. These three extracts of medicinal plant leaves exhibited inhibition. All extract inhibited mycelial at various level in that Coriandrum sativum Linn show strong inhibition the Sclerotium rolfsii, this followed subsequent by Mentha piperita Linn with moderate inhibition. Whereas Azadirchta indica ( neem) reveal least inhibited mycelial growth.

\section{References}

[1] Martin, C.and H.Torres, Comparative sensitive of Rhizoctonia solani and Rhizoctonia fungi like to selected fungicides in vitro. Physiopathology, 74 (7): 778-781, 1989.

[2] Bodde, T.Entomologist probe chemical of defenses and natural aninmies. Biol. Sci., 32: 308-311, 1982.

[3] Islam, M.B. Toxicity and fate of acetyl chromines in pest insects A.C.S.Symposium Series 387.AM.Chem.Soc.Washington, pp: 44-58, 1989.

[4] Tripathi, M., Dubey N.K. and Shulkla, A.K.(2008), Use of some essential oil of post-harvest botanical fungicides in the management of grey mould of grapes caused by Botrytis Cinerea.World J. Microbiol Biotechnol, 24: 3946, 2008.

[5] Kubo M, Kimura Y, Shin H, Tani T, Namba K, Shoyakugaku Zasshi, 35, 58-61, 1981.

[6] Cutler, H.G. and Culter, S.J. Biological active natural product: Agrochemical CRS Prees, Boca Raton: USA: 299, 1999.

[7] Dhingra, O.D. and Sinclair, J.B. "Basic Plant Pathology Methods". CBS Publishers. 7. 232, 1985.

\section{Volume 5 Issue 6, June 2016 www.ijsr.net}




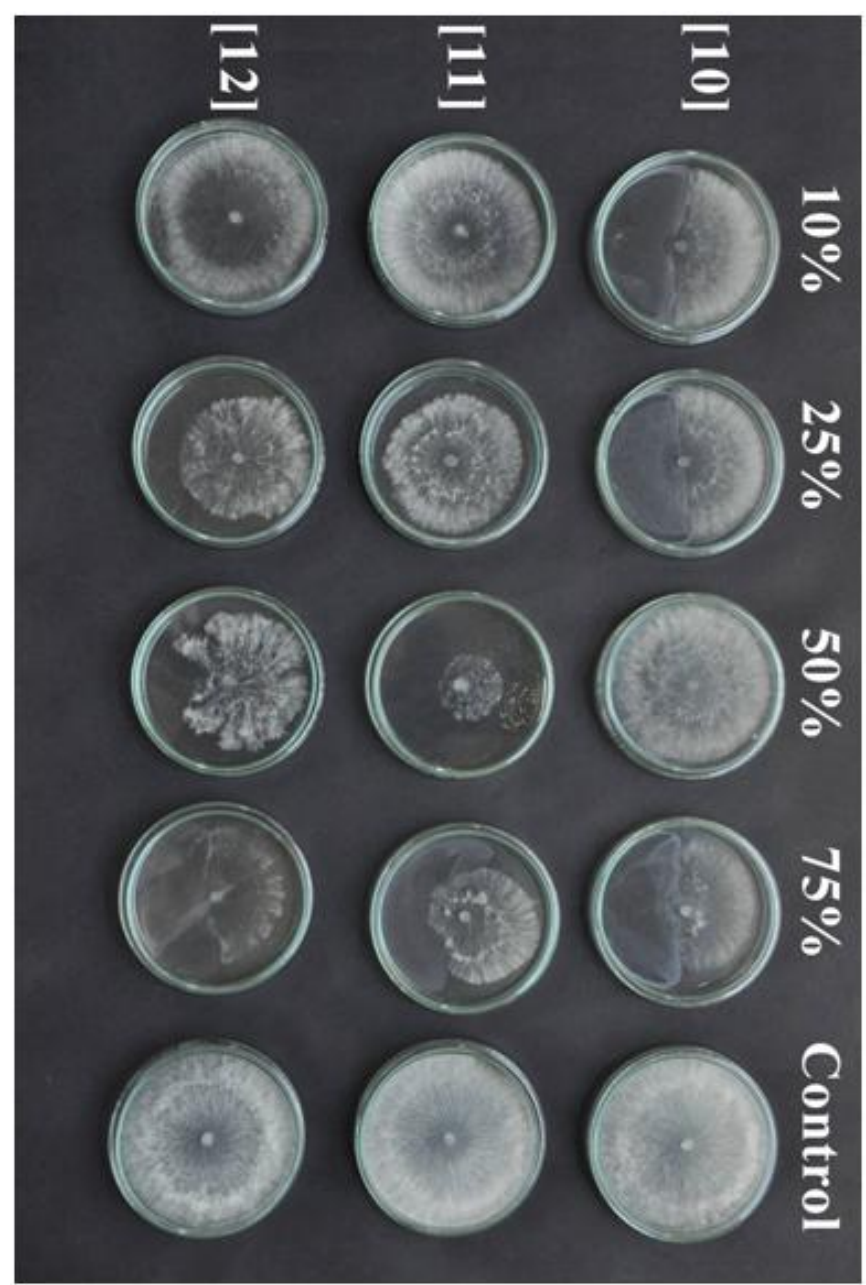

Figure 1 The figure [10] is Azadirachta indica (neem), Coriandrum satavium Linn [11] of Mentha piperita Linn, and [12] Azadirachta indica (neem) leaves extract of $10 \%$, $25 \%, 50 \%, 75 \%$ with $100 \%$ (control).

\section{Author Profile}

Uzma Quadri received the B.Sc. degree from Yeshwant Mahavidylaya Nanded and M.Sc. degrees in Botany from Science in 2004 and 2007, respectively. Now she is with Research program conducting in Dr. Rafiq Zakaria Women College Aurangabad.

Volume 5 Issue 6, June 2016 www.ijsr.net 